UDC 616.448-008.61:[616.441+616.45+616.36]-07-092.9:546.15

https://doi.org/10.26641/2307-0404.2020.2.206793

\title{
O.I. Ryabukha
}

\section{WEIGHT OF THE THYROID, ADRENAL GLANDS, AND THE LIVER OF WHITE RATS IN THE CONDITIONS OF HYPERTHYROIDISM: THE POSSIBILITY OF APPLYING INDICES CHANGES AS SCREENING-MARKERS FOR DETERMINING BODY STATUS EFFECTED BY ORGANIC AND INORGANIC IODINE}

Lviv Medical Institute

Department of Anatomy, Physiology and Pathology

Polishchuk str., 76, Lviv, 79018, Ukraine

Львівський медичний інститут

кафедра анатомії, фізіології та патології

(зав. - к. мед. н., дои.. О.І. Рябуха)

вул. Полішука, 76, Львів, 79018, Україна

e-mail:oriabuha@ukr.net

\author{
Цитування: Медичні перспективи. 2020. Т. 25, № 2. С. 149-155
}

Cited: Medicni perspektivi. 2020;25(2):149-155

Key words: organ weight, thyroid gland, adrenal glands, liver, hyperthyroidism

Ключові слова: маса внутрішніх органів, щзитоподібна залоза, надниркові залози, печінка, гіпертиреоз

Ключевые слова: масса внутренних органов, щъитовидная железа, надпочечники, печень, гипертиреоз

\begin{abstract}
Weight of the thyroid, adrenal glands, and the liver of white rats in the conditions of hyperthyroidism: the possibility of applying indices changes as screening-markers for determining body status effected by organic and inorganic iodine. Ryabukha O.I. Despite the available information on the interaction between the thyroid gland activity and that of the adrenal glands, and the liver involvement in their hormones metabolism, the study of the connection existing between these organs in hyperthyroidism is still incomplete. Changes in the weight indices values of the thyroid and adrenal glands and the liver of 90 non-linear white male rats were studied. Animals received histologically verified minimally active (21 $\mu \mathrm{g}$ iodine per $\mathrm{kg}$ body weight), moderate (50 $\mu \mathrm{g}$ iodine per $\mathrm{kg}$ body weight), and significant (100 $\mu \mathrm{g}$ iodine per $\mathrm{kg}$ body weight) doses of organic and inorganic iodine during 30 days under the model hyperthyroidism conditions. It was found that consumption of organic and inorganic iodine at a minimal dose approximates the digital values of adrenal gland and those of the liver of the intact animals. Consumption of a moderate organic iodine dose is accompanied by a decrease in the previously achieved values of the thyroid weight index by $17.28 \%$, and the increase in the liver weight index by 19.66\%. When consuming a moderate amount of inorganic iodine, the largest change in the values achieved was the liver weight index which increased by $13.76 \%$. Consumption of organic and inorganic iodine compounds in a significant dose is accompanied by further changing in the studied parameters. When consuming organic iodine the thyroid weight index grows by 10.44\%, that of the adrenal glands - by $13.33 \%$, the liver - by $34.52 \%$. Consuming of inorganic iodine is accompanied by a rapid increase in the thyroid glands weight index by $21.25 \%$, that of the liver - by $34.31 \%$. The established indicates the existence of functional communication between the studied organs; the effect depends on the chemical nature and dose of iodine consumed. The existing functional dependence gives grounds to apply changes in the weight index of the thyroid gland, adrenal glands and the liver as screening-markers to determine the body's condition in hyperthyroidism.
\end{abstract}

Реферат. Маса щитоподібних, надниркових залоз та печінки білих щурів в умовах гіпертиреозу: можливість застосування змін показників у якості скринінг-маркерів визначення стану організму при впливі органічного і неорганічного йоду. Рябуха О.І. Попри наявні відомості про взаємну залежність діяльності щитоподібної залози $і$ надниркових залоз та участь печінки в метаболізмі їхніх гормонів, дослідження зв'язку, який існує між циими органами при гіпертиреозі, проведене щее в недостатньому обсязі. Вивчалися зміни показників коефіцієнтів маси щиттоподібних і надниркових залоз та печінки 90 білих нелінійних щурів-самиів. Впродовж 30 днів перебування в змодельованих умовах гіпертиреозу тварини отримували гістологічно визначені мінімально діючу (21 мкг/кг маси тіла), помірну (50 мкг/кг маси тіла) $i$ значну (100 мкг/кг маси тіла) дози органічного $і$ неорганічного йоду. Установлено, щчо приймання органічного $i$ неорганічного йоду в незначній дозі наближає ицфрові значення коефіцієнтів мас надниркових залоз $і$ печінки до показників інтактних тварин. Приймання помірної дози органічного йоду супроводжується зменшенням, 
щзодо попередньо досягнутих значень, коефіцієнта маси щзитоподібних залоз на 17,28\% та збільшенням коефіцієнта маси печінки на 19,66\%. При споживанні помірної кількості неорганічного йоду найбільших змін щзодо досягнутих величин зазнає коефіцієнт маси печінки, який зростає на 13,76\%. Споживання сполук органічного і неорганічного йоду в значній дозі супроводжується подальшими змінами досліджуваних показників. При прийманні органічного йоду коефіџієнт маси щитоподібних залоз зростає на 10,44\%, надниркових залоз - на 13,33\%, печінки - на 34,52\%. Приймання неорганічного йоду супроводжується стрімким зростанням коефіцієнта маси щитоподібних залоз на 21,25\%, печінки - на 34,31\%. Установлене вказує на наявність функціонального зв'язку між досліджуваними органами; при цъьому результат впливу залежить від хімічної природи і дози спожитого йоду. Наявна функціональна залежність дає підстави застосовувати зміни показників маси щцитоподібної залози, надниркових залоз та печінки в якості скринінг-маркерів визначення стану організму при гіпертиреозі.

In recent years, the state of the body is ever more frequently determined by analyzing the data obtained by weighing or measuring of various morphometric parameters. Thus, the study of the correlation between the body weight and the internal organs' weight and volume is rather perspective $[2,13,14$, . Applying screening studies aimed at determining changes in the status of the organs, which, being significant for the body, do not belong to the same physiological system, but have functional links with each other is expedient $[10,11]$. In this aspect, the thyroid gland is of considerable interest, being directly or indirectly connected with the course of many processes [8]. Since the thyroid gland is actively involved in the activity of the "hypothalamic-pituitary-thyroid" axis, by means of which the thyroid gland is linked with the adrenal glands, the state of the thyroid gland matters in responses to stress [4, 9]. In particular, the dependence of biochemical parameters of the liver condition and its morphofunctional characteristics on the changes in the thyroid gland functional activity has been traced [5]. However, it is the thyroid pathology that occupies a leading position among endocrine diseases [15]. A fairly common disorder of thyroid activity is hyperthyroidism, which is characterized by the acceleration of both synthesis and catabolism of proteins, which leads to their metabolism disorders [3]. In the meantime, the relationship between the liver thyroid, and adrenal glands in hyperthyroidism has not been well studied.

The purpose of the research project was to study the influence of iodine with different chemical nature on the thyroid gland weight and on the weight of adrenal glands and the liver, functionally connected with the thyroid gland, in the conditions of the increased functional activity of thyroid gland, in order to identify weight changes of these organs as markers of changes in the body status.

MATERIALS AND METHODS OF RESEARCH

A study of 30 days duration was performed on 90 non-linear white male rats with an initial body weight of $140-160 \mathrm{~g}$, with 80 animals being on a synthetic isocaloric starch-casein diet, deficient in iodine content. The source of water-soluble vitamins in the diet was a standard vitamin solution, made with distilled water; fat-soluble vitamins and $\alpha$ tocopherol came from unrefined sunflower oil. All nutrients were added to the food mixture in quantities recommended for animals of this species and age; the drinking bowls were filled with distilled water, which animals consumed ad libitum. Cages were cleaned daily before filling the fodder with the feeders. The state of subclinical hyperthyroidism was induced by applying thyreoidinum (Belgorodvitaminy LLC, Russia), which was consumed physiologically with food in a histologically determined amount of $15 \mathrm{mg}$ per $100 \mathrm{~g}$ body weight. The study was carried out in the spring-summer period to unify the study and to avoid the influence of seasonal and temperature variations. The functional activity of the thyroid gland was affected by the compounds of organic and inorganic iodine, which were added to the food mixture. Organic iodine was consumed with the iodine-protein components from the Black Sea red algae Phyllophora nervosa (DC.) Grev., inorganic iodine with a potassium iodide solution, prepared with distilled water. The choice of iodine doses was made taking into account that the dose of iodine $50 \mu \mathrm{g}$ per $\mathrm{kg}$ body weight is sufficient for normal functioning of the thyroid gland. Both iodine-containing substances were introduced in the amounts ensuring administration of a histologically verified minimally active ( $21 \mu \mathrm{g}$ per $\mathrm{kg}$ body weight), moderate $(50 \mu \mathrm{g}$ per $\mathrm{kg}$ body weight) and significant $(100 \mu \mathrm{g}$ per $\mathrm{kg}$ body weight) iodine doses [12].

The rats were divided into 9 groups of 10 animals in each. The rats of group 1, which were universal controls $\left(\mathrm{C}_{1}\right)$ for animals of other groups, were kept on the complete, commonly used vivarium fodder. Rats of group 2 were on the iodine deficient diet and served as a control $\left(\mathrm{C}_{2}\right)$ to determine the indices of the organs' weight under the conditions of iodine deficiency in the diet. The animals of groups 3-9 took thyreoidinum, while the rats of group 3 were a control $\left(\mathrm{C}_{3}\right)$ in determining the features of the both iodine-containing drugs' effect on the weight of the 
internal organs under study. To the diet of the rats in groups $4,5,6$, the amount of 21,50 and 100 micrograms of organic iodine was added, respectively. Rats of groups 7, 8, 9 received the same amount of iodine of inorganic chemical nature.

At the end of the study period, the animals were decapitated under the ether anesthesia. Experiments with the use of laboratory animals were carried out in compliance with the Law of Ukraine "On Protection of Animals from Cruel Treatment" (No. 3447-IV of February 21, 2006), as well as the "General Ethical Principles of Animal Experiments" adopted by the 1st National Congress on Bioethics (Kyiv, 2001) following the requirements of the Bioethics Committee of the Lviv Medical Institute (Protocol No. 22 of May 15, 2017), agreed with the provisions of the "European Convention for the Protection of Vertebrate Animals Used for Experimental and Other Scientific Purposes" (Strasbourg, 1986). The thyroid and adrenal glands and the liver were separated from the connective tissue and weighed. The absolute weight of the thyroid and adrenal glands was determined by means of the Bt500 torsion balance (absolute error of the parameters $\pm 1.0 \mathrm{mg}$ ), the liver - with the BLA-200-M analytical balance (measurement range $\pm 10 \mathrm{mg}$ ); laboratory scales with an error index of $\pm 0.5 \mathrm{~g}$ were used to determine the body weight. Relative weights of organs (organs weight index) were calculated using formulas (1) and (2):

$$
k=\frac{a \cdot 100}{b}
$$

where $k$ is the weight index of the liver; $a$ - absolute weight of the liver; $b$ - body weight of the animal; 100 - conversion factor in determining the relative weight of the liver;

$$
k=\frac{a \cdot 1000}{b}
$$

where $k$ is the weight index of the thyroid/adrenal glands; $a$ - absolute weight of the thyroid/adrenal glands; $b$ - body weight of the animal; 1000 - conversion factor in determining the relative weight of the thyroid/adrenal glands.

The digital results were presented in the form of the arithmetic mean and its standard error $(\mathrm{M} \pm \mathrm{m})$. The mathematical processing of the data obtained was carried out using licensed programme StatSoft Statistica v6.0 (serial 31415926535897); the results were compared to each other by comparing the numerical indices obtained with the consumption of identical doses of iodine from the both iodine-containing compounds, and by studying the effect of their increasing quantities. The reliability of the results was assessed according to Student's $t$-test at a level of statistical significance $\mathrm{p} \leq 0.05$ [1]. The criterion for their assessment was the approximation of the obtained indices to the intact animals' parameters of group 1.

\section{RESULTS AND DISCUSSION}

The digital parameters of the study results are presented in table.

Analysis of the data obtained showed that administering of the exogenous thyroid hormone (group 3 rats) resulted in a rapid reduction of the thyroid glands weight index by $58 \%$ compared to the intact animals of group 1 and by $40 \%$ compared to those of group 2; in both cases $-p<0.01$. At the same time, the digital values of the adrenal glands and liver weight indices in rats of the discussed group were significantly higher than the similar indices in the intact animals (by $20 \%$ and $32.1 \%$, respectively) and in the animals of group $\mathrm{C}_{2}$ (by $38.5 \%$ and $17.84 \%$, respectively; $p<0.01$ ). Such a nature of changes in the weight indices of these internal organs can be logically regarded as a manifestation of a significant thyreoidinum-induced disorder in the functional balance (in particular, its ability to cause a stress-inducing effect), as well as suppression of the thyroid gland hormonal function and disorders of thyroid and steroid hormones metabolism.

Consuming of organic iodine in the amount of 21 $\mu \mathrm{g}$ by the animals of group 4 contributed to the rapid (by $28.57 \%$ ) growth in the digital values of the thyroid gland's weight index compared to the control group $\mathrm{C}_{3}(\mathrm{p}<0.05)$. The above mentioned effect occurred simultaneously with the normalization of the adrenal glands weight index (compared to the control group $\mathrm{C}_{1}, \mathrm{p}>0.05$ ) and the tendency to normalization of the liver weight index, which decreased by $19 \%$ (compared to the control group $\mathrm{C}_{3}, \mathrm{p}<0.05$ ). Despite the fact that the values of the thyroid weight index were by $46 \%$ less than in the intact animals $(p<0.01)$, we consider this nature of changes in the weight indices of the studied internal organs to be a sign of significant mitigation of the functional hyperthyroidism manifestations, in particular, improvement the morphofunctional status of the adrenal glands and the liver and optimizing the thyroid and steroid hormones metabolism.

The consumption of organic iodine in higher doses was accompanied by changes (relative to the achieved values) of the thyroid gland weight index simultaneously with increasing digital values of the adrenal glands and the liver weight indices. The severity of the changes was proportional to the amount of organic iodine consumed. Thus, under the conditions of receiving $50 \mu \mathrm{g}$ of organic iodine (group 5), the adrenal glands weight index was still at the level achieved by consuming its lower dose of 
$21 \mu \mathrm{g}(\mathrm{p}>0.05)$, while the values of the of the thyroid gland's and the liver's weight indices were quite close to the indices in group $C_{3}-0.067 \pm 0.003$ units compared to $0.063 \pm 0.002$ units and $42.0 \pm 2.4$ units compared to $43.6 \pm 2.4$ units $(\mathrm{p}<0.05)$. When consuming $100 \mu \mathrm{g}$ of organic iodine by the animals of group 6, the digital values of all the discussed parameters changed: values of the adrenal gland's and the liver's weight indices exceeded the parameters of rats in the control group 3 by $17.46 \%$ and $29.59 \%$, respectively $(p<0.05)$. Such changes in the weight indices of the internal organs, jointly participating in the hormonopoiesis and thyroid hormones metabolism, indicate the activating effect caused by organic iodine in a significant dose on all links of these hormones formation and transformation.

Weight of the body, thyroid glands, adrenal glands, liver and weight indices of these internal organs in white rats under the influence of organic and inorganic iodine consumption in the conditions of thyreoidinum-induced hyperthyroidism, $\mathrm{M} \pm \mathbf{m}$

\begin{tabular}{|c|c|c|c|c|c|c|c|}
\hline \multirow{2}{*}{$\begin{array}{l}\text { Animal } \\
\text { groups }\end{array}$} & \multirow{2}{*}{$\begin{array}{l}\text { Animal body } \\
\text { weight, } \\
\text { (g) }\end{array}$} & \multicolumn{2}{|c|}{ Thyroid Glands } & \multicolumn{2}{|c|}{ Adrenal Glands } & \multicolumn{2}{|c|}{ Liver } \\
\hline & & $\begin{array}{c}\text { organ weight, } \\
\text { (g) }\end{array}$ & $\begin{array}{l}\text { weight index, } \\
\text { (units) }\end{array}$ & $\begin{array}{c}\text { organ weight, } \\
\text { (g) }\end{array}$ & $\begin{array}{l}\text { weight index, } \\
\text { (units) }\end{array}$ & $\begin{array}{c}\text { organ weight, } \\
\text { (g) }\end{array}$ & $\begin{array}{l}\text { weight index, } \\
\text { (units) }\end{array}$ \\
\hline $\begin{array}{l}1\left(C_{1}\right) \\
n=10\end{array}$ & $176.0 \pm 3.1$ & $0.022 \pm 0.0008$ & $0.15 \pm 0.008$ & $0.035 \pm 0.0001$ & $0.15 \pm 0.002$ & $9.0 \pm 0.37$ & $33.1 \pm 0.52$ \\
\hline $\begin{array}{l}2\left(C_{2}\right) \\
n=10\end{array}$ & $224.0 \pm 0.9$ & $0.025 \pm 0.0008$ & $0.105 \pm 0.003$ & $\mathbf{0 . 0 3 1} \pm 0.0007$ & $0.13 \pm 0.006$ & $9.1 \pm 0.59$ & $37.2 \pm 0.23$ \\
\hline $\begin{array}{l}3\left(C_{3}\right) \\
n=10\end{array}$ & $\begin{array}{c}213.3 \pm 0.51 \\
p<0.01(1) \\
p<0.05(2)\end{array}$ & $\begin{array}{c}0.013 \pm 0.0004 \\
p<0.01(2)\end{array}$ & $\begin{array}{c}0.063 \pm 0.002 \\
p<0.01(1) \\
p<0.01(2)\end{array}$ & $\mathbf{0 . 0 3 8} \pm \mathbf{0 . 0 0 3 7}$ & $\begin{array}{c}0.18 \pm 0.05 \\
p<0.05(1) \\
p<0.01(2)\end{array}$ & $9.3 \pm 0.41$ & $\begin{array}{l}43.6 \pm 2.4 \\
p<0.01(1) \\
p<0.01(2)\end{array}$ \\
\hline $\begin{array}{l}4 \\
n=10\end{array}$ & $\begin{array}{c}261.9 \pm 0.56 \\
p<0.01(1) \\
p<0.01(3)\end{array}$ & $\begin{array}{c}0.021 \pm 0.0008 \\
p<0.01(3)\end{array}$ & $\begin{array}{c}0.081 \pm 0.003 \\
p<0.01(1) \\
p<0.01(3)\end{array}$ & $0.038 \pm 0.0011$ & $0.15 \pm 0.004$ & $\begin{array}{c}9.2 \pm 0.35 \\
p<0.05(3)\end{array}$ & $\begin{array}{l}35.1 \pm 1.8 \\
p<0.05(3)\end{array}$ \\
\hline $\begin{array}{l}5 \\
n=10\end{array}$ & $\begin{array}{c}262.0 \pm 2.55 \\
p<0.01(1) \\
p<0.01(3)\end{array}$ & $\begin{array}{c}0.014 \pm 0.0046 \\
p<0.05(4)\end{array}$ & $\begin{array}{c}0.067 \pm 0.003 \\
p<0.01(1) \\
p<0.01(4)\end{array}$ & $0.039 \pm 0.0047$ & $0.15 \pm 0.005$ & $\begin{array}{l}11.1 \pm 0.63 \\
p<0.01(3) \\
p<0.05(4)\end{array}$ & $\begin{array}{l}42.0 \pm 2.4 \\
p<0.01(1) \\
p<0.05(4)\end{array}$ \\
\hline $\begin{array}{l}6 \\
n=10\end{array}$ & $\begin{array}{c}246.8 \pm 0.5 \\
p<0.01 \text { (1) } \\
p<0.01(3) \\
p<0.01(4) \\
p<0.01(5)\end{array}$ & $\begin{array}{c}0.018 \pm 0.0008 \\
p<0.01(3) \\
p<0.05(5)\end{array}$ & $\begin{array}{c}0.074 \pm 0.003 \\
p<0.01(1) \\
p<0.01(3) \\
p<0.01(4) \\
p<0.01(5)\end{array}$ & $\begin{array}{c}0.043 \pm 0.012 \\
p<0.01(3) \\
p<0.01(4) \\
p<0.01(5)\end{array}$ & $0.17 \pm 0.006$ & $\begin{array}{l}11.1 \pm 0.74 \\
p<0.05(3) \\
p<0.05(4)\end{array}$ & $\begin{array}{l}56.5 \pm 4.5 \\
p<0.01(1) \\
p<0.01(3) \\
p<0.01(4) \\
p<0.01(5)\end{array}$ \\
\hline $\begin{array}{l}7 \\
n=10\end{array}$ & $\begin{array}{c}236.1 \pm 4.36 \\
p<0.01(3) \\
p<0.01(4)\end{array}$ & $\begin{array}{c}0.018 \pm 0.0011 \\
p<0.01(3)\end{array}$ & $\begin{array}{c}0.08 \pm 0.008 \\
p<0.01(1) \\
p<0.05(3)\end{array}$ & $\begin{array}{c}0.042 \pm 0.0014 \\
p<0.01(3) \\
p<0.01(4)\end{array}$ & $0.17 \pm 0.005$ & $\begin{array}{c}8.4 \pm 0.44 \\
p<0.05(3) \\
p<0.05(4)\end{array}$ & $\begin{array}{l}35.6 \pm 1.3 \\
p<0.01(3)\end{array}$ \\
\hline $\begin{array}{l}8 \\
n=10\end{array}$ & $\begin{array}{c}234.5 \pm 4.17 \\
p<0.01(3) \\
p<0.01(5)\end{array}$ & $\begin{array}{c}0.019 \pm 0.0011 \\
p<0.01(3) \\
p<0.05(5)\end{array}$ & $\begin{array}{c}0.08 \pm 0.005 \\
p<0.01 \text { (1) } \\
\mathbf{p}<0.01 \text { (3) } \\
\mathbf{p}<0.05(5)\end{array}$ & $\begin{array}{c}0.043 \pm 0.0013 \\
p<0.01(3) \\
p<0.01(5)\end{array}$ & $\begin{array}{c}0.18 \pm 0.069 \\
p<0.05(1)\end{array}$ & $\begin{array}{c}9.5 \pm 0.32 \\
p<0.01(5) \\
p<0.05(7)\end{array}$ & $\begin{array}{l}40.5 \pm 1.5 \\
p<0.01(1) \\
p<0.05(3) \\
p<0.05(7)\end{array}$ \\
\hline $\begin{array}{l}9 \\
n=10\end{array}$ & $\begin{array}{c}198.0 \pm 5.29 \\
p<0.01(1) \\
p<0.01(3) \\
p<0.01(6) \\
p<0.01(7) \\
p<0.01(8)\end{array}$ & $\begin{array}{c}0.019 \pm 0.0006 \\
p<0.01(3)\end{array}$ & $\begin{array}{c}0.097 \pm 0.006 \\
p<0.01(1) \\
p<0.01(3) \\
p<0.01(6) \\
p<0.01(7) \\
p<0.01(8)\end{array}$ & $\begin{array}{c}\mathbf{0 . 0 3 8} \pm 0.0016 \\
\mathbf{p}<0.05(6) \\
\mathbf{p}<0.05(7) \\
\mathbf{p}<0.05(8)\end{array}$ & $\begin{array}{c}0.19 \pm 0.029 \\
p=0.05(1)\end{array}$ & $\begin{array}{c}8.5 \pm 0.7 \\
p<0.05(6)\end{array}$ & $\begin{array}{l}54.6 \pm 4.3 \\
p<0.01(1) \\
p<0.01(3) \\
p<0.01(7) \\
p<0.01(8)\end{array}$ \\
\hline
\end{tabular}

Note: at $\mathrm{p}>0.05$ the indices were not entered in the table; numbers in brackets indicate the number of the group which the comparison was made with.

Under the conditions of consuming $21 \mu \mathrm{g}$ of inorganic iodine, the thyroid gland weight index (rat group 7) was higher (by 26.98\%) than that in the control group $C_{3}(p<0.05)$. Besides, the values of the adrenal glands and the liver weight indices in the discussed group of animals were lower than the control $\mathrm{C}_{3}$ group parameters by $5.6 \%$ and $18.35 \%$, respectively $(p<0.05)$, herewith the liver weight indices were close to the indices of the intact animals in group $\mathrm{C}_{1}$.

A growth in the consumed inorganic iodine dose up to $50 \mu \mathrm{g}$ (group 8) had a slight effect on the 
thyroid and adrenal glands weight indices $(0.08 \pm 0.005$ units and $0.18 \pm 0.069$ units compared to the results of animals in group $7-p>0.05$ ). At the same time, liver weight index has grown by $13.76 \%$ $(p<0.05)$. Taking into account that the digital values of the thyroid glands weight index in animals of the discussed group were smaller than those of the intact animals by $46.7 \%$, and the weight indices of the adrenal glands and the liver were higher by $20 \%$ and $22.36 \%$, respectively $(p<0.05)$, we believe that, against the background of the thyreoidinum action, consumption of inorganic iodine in the amount under study impairs hormonopoiesis and metabolic transformations of thyroid hormones. A similar way of changes in the discussed indices was also observed in animals of group 9, to whose food diet $100 \mu \mathrm{g}$ of inorganic iodine was added.

Thus, consumption of organic iodine in the amounts close to the minimally acting and moderate doses ( 21 and $50 \mu \mathrm{g}$ per $\mathrm{kg}$ body weight) is accompanied by an increase in the weight indices parameters of the thyroid glands by $28.57 \%$ and $6.35 \%$ (compared to the control $\mathrm{C}_{3}$ ), with simultaneous normalizing of the adrenal glands weight index and the tendency toward normalization of the liver weight index. The above mentioned gives us the grounds to believe that under the conditions of subclinical hyperthyroidism, the consumption of organic iodine in these doses has a positive effect on the general body status. The effect of inorganic iodine in similar doses is less pronounced, as it is evidenced by the lack of normalization in the digital values of weight indices of the studied internal organs. Meanwhile, consumption of iodine in the significant dose (100 $\mu \mathrm{g}$ per kg body weight) of both iodine-containing substances leads to an increase of the thyroid gland's weight indices compared to the values obtained when taking $50 \mu \mathrm{g}$ of iodine per $\mathrm{kg}$ of body weight (by $10.45 \%$ for organic and $21.25 \%$ for inorganic iodine), which in our opinion is a sign of their functional activity increase, while simultaneous growth of the adrenal glands' and the liver's weight indicates a deterioration in the general body status. The effect of a iodine-containing drug depends on chemical nature of the iodine consumed: the effect achieved by administering of organic iodine is more pronounced than that of inorganic iodine in the similar dose, which may be the result of a more activizing effect of organic iodine compounds.

Thus, the results of our studies are consistent with reports from a number of researchers concerning the correlation between the thyroid gland and the adrenal glands and between the thyroid gland and the liver. Thus, in particular work, [6] provides information on the functional correlation existing between the thyroid gland and the liver in hyperthyroidism, and it was emphasized on rather frequent combination of pathology of these organs. The existence of a correlation between the adrenal glands and the thyroid gland's condition was reported in $[4,7]$. In view of the above information, we consider a clear tendency, established by us, to normalize the weight parameters of adrenal glands and the liver as organs pertaining to the activity of the thyroid gland, to be an informative sign (screening marker) of effect of the iodine-containing compounds on the body. At the same time, determining the organ weight in vivo is possible through the mathematical transformation of its length, width and height parameters obtained during other studies. This makes the presented approach to testing the body condition through determining thyroid, adrenal and liver weight available for practical application and promising for research in the field of endocrinology, hygiene, toxicology.

\section{CONCLUSION}

1. It was found that consumption of organic and inorganic iodine at a minimally acting dose approximates the digital values of adrenal gland and liver weight indices to those of the intact animals.

2. Consumption of a moderate organic iodine dose is accompanied by a decrease in the previously achieved values of the thyroid weight index by $17.28 \%$, and the increase in the liver weight index by $19.66 \%$. When consuming a moderate amount of inorganic iodine, the largest change in the values achieved was the liver weight index which increased by $13.76 \%$.

3. Consumption of organic and inorganic iodine compounds in a significant dose is accompanied by further changing in the studied parameters. When consuming organic iodine, the thyroid weight index grows by $10.44 \%$, that of the adrenal glands - by $13.33 \%$, the liver - by $34.52 \%$. Consuming of inorganic iodine is accompanied by a rapid increase in the thyroid glands weight index by $21.25 \%$, that of the liver - by $34.31 \%$.

4. The changes of the thyroid, adrenal glands and the liver weight, which occur when consuming iodine-containing substances, indicate that these internal organs belong to a single functional module. Taking into account the significance of these organs for the body activity, the existing functional dependence gives grounds to apply changes in the weight index of the thyroid gland, adrenal glands and the liver as screening-markers to determine te body condition in hyperthyroidism.

Conflict of interests. The authors declare no conflict of interest.

The prospect of further research is seen in the study of the thyroid gland's hormonal activity features under the effect of iodine with various chemical nature. 


\section{REFERENCES}

1. Antomonov MYu. [Mathematical treatment and analysis of medico-biological data]. 2nd ed. Kyiv: Interregional Publishing Center "Medinform"; 2017. p. 579 Russian.

2. Mubbunu L, Bowa K, Petrenko V, Silitongo M. Correlation of internal organ weights with body weight and body height in normal adult zambians: A case study of Ndola Teaching Hospital. Anat Res Int. 2018;2018:1-5. doi: https://doi.org/10.1155/2018/4687538

3. Devereaux D, Tewelde SZ. Hyperthyroidism and thyrotoxicosis. Emerg Med Clin N Am. 2014;32(2):27792. doi: https://doi.org/10.1016/j.emc.2013.12.001

4. Ferlazzo A, Cravana C, Fazio E, Medica P. Is there an interplay between the hypothalamus-pituitarythyroid and the hypothalamus-pituitary-adrenal axes during exercise-stress coping in horses? J Equine Vet Sci. 2018;62:85-97. doi: //doi.org/10.1016/j.jevs.2017.08.018

5. Malespin M, Nassri A. Endocrine Diseases and the Liver: An Update. Clin Liver Dis. 2019;23(2):233246. doi: https://doi.org/10.1016/j.cld.2018.12.006

6. Mansourian AR. Liver functional behavior during thyrotoxicosis: a review. Journal of Biological Sciences. 2013;13(8):665-78.

doi: https://doi.org/10.3923/jbs.2013.665.678

7. Manojlović-Stojanoski MN, Filipović BR, Nestorović NM, Šošić-Jurjević BT, Milošević VLj. Morphofunctional characteristics of rat fetal thyroid gland are affected by prenatal dexamethasone exposure. Steroids. 2014;84:22-9.

doi: https://doi.org/10.1016/j.steroids.2014.03.006

8. Mullur R, Liu YY, Brent GA. Thyroid hormone regulation of metabolism. Physiol Rev. 2014;94(2):35582. doi: https://doi.org/10.1152/physrev.00030.2013

9. Ranabir S, Reetu K. Stress and hormones. Indian $\mathrm{J}$ Endocrinol Metab. 2011;15(1):18-22. doi: https://doi.org/10.4103/2230-8210.77573
10. Ryabukha O, Dronyuk I. Applying regression analysis to study the interdependence of thyroid, adrenal glands, liver, and body weight in hypothyroidism and hyperthyroidism. Proceedings of the 2nd International Workshop on Informatics \& Data-Driven Medicine (IDDM 2019). Lviv, Ukraine, November 11-13, 2019. CEUR Workshop Proceedings-Series. 2019;2488:155-164. Available from:

https://www.scopus.com/inward/record.url?eid=2-s2.085074669256\&partnerID=MN8TOARS

11. Ryabukha $\mathrm{O}$, Greguš $\mathrm{ml} \mathrm{M}$. Correlation analysis as a thyroid gland, adrenal glands, and liver relationship tool for correcting hypothyroidism with organic and inorganic iodine. Procedia Comput Sci. 2019;160:598603. https://doi.org/10.1016/j.procs.2019.11.041

12. Ryabukha OI. Search for markers of changes of the synthetic activity of thyrocyte under the influence of iodine reception in iodine deficiency conditions. World of Medicine and Biology. 2018;65(3):179-85. doi: https://dx.doi.org/10.26724/2079-8334-2018-3-65179-185

13. Sheikhazadi A, Sadr SS, Ghadyani MH, Taheri SK, Manouchehri AA, Nazparvar B et al. Study of the normal internal organ weights in Tehran's population. J Forensic Leg Med. 2010;17(2):78-83. doi: https://doi.org/10.1016/j.jflm.2009.07.012

14. Caglar V, Kumral B, Uygur R, Alkoc O, Ozen O, Demirel H. Study of volume, weight and size of normal pancreas, spleen and kidney in adults autopsies. Forensic Medicine and Anatomy Research. 2014;2:63-9. doi: https://dx.doi.org/10.4236/fmar.2014.23012

15. Vanderpump MP. The epidemiology of thyroid disease. $\mathrm{Br}$ Med Bull. 2011;99(1):39-51. doi: https://doi.org/10.1093/bmb/ldr030

\section{СПИСОК ЛІТЕРАТУРИ}

1. Антомонов М. Ю. Математическая обработка и анализ медико-биологических данных. 2-е изд. Киев: Межрегиональный издательский центр «Мединформ», 2017. 579 с.

2. Correlation of internal organ weights with body weight and body height in normal adult zambians: A case study of Ndola Teaching Hospital / L. Mubbunu et al. Anat Res Int. 2018. Vol. 2018. P. 1-5. DOI: https://doi.org/10.1155/2018/4687538

3. Devereaux D., Tewelde S. Z. Hyperthyroidism and thyrotoxicosis. Emerg Med Clin N Am. 2014. Vol. 32, No. 2. P. 277-292.

DOI: https://doi.org/10.1016/j.emc.2013.12.001

4. Is there an interplay between the hypothalamuspituitary-thyroid and the hypothalamus-pituitary-adrenal axes during exercise-stress coping in horses? / A. Ferlazzo et al. J Equine Vet Sci. 2018. Vol. 62. P. 8597. DOI: https://doi.org/10.1016/j.jevs.2017.08.018
5. Malespin M., Nassri A. Endocrine Diseases and the Liver: An Update. Clin Liver Dis. 2019. Vol. 23, No. 2. P. 233-246.

DOI: https://doi.org/10.1016/j.cld.2018.12.006

6. Mansourian A. R. Liver functional behavior during thyrotoxicosis: a review. Journal of Biological Sciences. 2013. Vol. 13, No. 8. P. 665-678. DOI: https://doi.org/10.3923/jbs.2013.665.678

7. Morpho-functional characteristics of rat fetal thyroid gland are affected by prenatal dexamethasone exposure / M. N. Manojlović-Stojanoski et al. Steroids. 2014. Vol. 84. P. 22-29.

DOI: https://doi.org/10.1016/j.steroids.2014.03.006

8. Mullur R., Liu Y. Y., Brent G. A. Thyroid hormone regulation of metabolism. Physiol Rev. 2014. Vol. 94, No. 2. P. 355-382.

DOI: https://doi.org/10.1152/physrev.00030.2013 
9. Ranabir S., Reetu K. Stress and hormones. Indian $J$ Endocrinol Metab. 2011. Vol. 15, No. 1. P. 18-22. DOI: https://doi.org/10.4103/2230-8210.77573

10. Ryabukha O., Dronyuk I. Applying regression analysis to study the interdependence of thyroid, adrenal glands, liver, and body weight in hypothyroidism and hyperthyroidism. Proceedings of the 2nd International Workshop on Informatics \& Data-Driven Medicine (IDDM 2019). Lviv, Ukraine, November 11-13, 2019. CEUR Workshop Proceedings-Series. 2019. Vol. 2488. P. 155-164. Available from:

https://www.scopus.com/inward/record.url?eid=2-s2.085074669256\&partnerID=MN8TOARS

11. Ryabukha O., Greguš $\mathrm{ml} \mathrm{M}$. Correlation analysis as a thyroid gland, adrenal glands, and liver relationship tool for correcting hypothyroidism with organic and inorganic iodine. Procedia Comput Sci. 2019. Vol. 160, P. 598-603. DOI: https://doi.org/10.1016/j.procs.2019.11.041
12. Ryabukha O. I. Search for markers of changes of the synthetic activity of thyrocyte under the influence of iodine reception in iodine deficiency conditions. World of Medicine and Biology. 2018. Vol. 65, No. 3. P. 179-185. DOI: https://dx.doi.org/10.26724/2079-8334-2018-3-65179-185

13. Study of the normal internal organ weights in Tehran's population / A. Sheikhazadi et al. J Forensic Leg Med. 2010. Vol. 17, No. 2. P. 78-83. DOI: https://doi.org/10.1016/j.jflm.2009.07.012

14. Study of volume, weight and size of normal pancreas, spleen and kidney in adults autopsies / V. Caglar et al. Forensic Medicine and Anatomy Research. 2014. Vol. 2. P. 63-69. DOI: https://dx.doi.org/10.4236/fmar.2014.23012

15. Vanderpump M. P. The epidemiology of thyroid disease. Br Med Bull. 2011. Vol. 99, No. 1. P. 39-51. DOI: https://doi.org/10.1093/bmb/ldr030

Стаття надійшла до редакції 09.11.2019 